УДК 343.98

DOI https://doi.org/10.32844/2618-1258.2019.3-2.30

ЛУБЕНЦОВ А.В.

\title{
ОСОБЛИВОСТІ ОФОРМЛЕННЯ ВИСНОВКУ СУДОВОЇ АВТОТЕХНІЧНОЇ ЕКСПЕРТИЗИ
}

У статті на основі аналізу наукових поглядів учених і норм чинного законодавства України визначено та охарактеризовано особливості оформлення висновку судової автотехнічної експертизи. Обгрунтовано, що результати оцінки висновку експерта стають підставами для проведення інших процесуальних дій, а отже, можуть або скоротити, або розширити строки досудового розслідування та вирішення справи по суті в суді. 3'ясовано, що в дослідницькій частині висновку експерта описуються процес дослідження та його результати, а також дається обгрунтування висновків із поставлених питань. Дослідницька частина повинна включати таке: відомості про стан об'єктів дослідження, застосовані методи (методики) дослідження, умови їх застосовування; посилання на ілюстрації, додатки та необхідні роз'яснення до них; експертну оцінку результатів дослідження. Опис процесу застосовування інструментальних методів дослідження та проведення експертних експериментів можуть обмежуватись викладенням кінцевих результатів. У зазначених випадках графіки, діаграми, таблиці, матеріали експертних експериментів мають зберігатись у наглядових експертних провадженнях і на вимогу органу (особи), який (яка) призначив (-ла) експертизу (залучив (-ла) експерта), можуть надаватись їм для ознайомлення. Визначено, що в заключній частині викладаються висновки за результатами дослідження у вигляді відповідей на поставлені запитання в послідовності, що визначена у вступній частині. На кожне з поставлених запитань має бути дано відповідь по суті або вказано, з яких причин неможливо вирішити питання. Якщо заключний висновок не може бути сформульований у стислій формі, допускається посилання на результати досліджень, викладені в дослідницькій частині. Зроблено висновок, що процес проведення автотехнічної експертизи складається із сукупності дій організаційного характеру керівника експертної установи та виконавця судової експертизи, а також дій пізнавального, дослідницького характеру судового експерта-автотехніка, спрямованих на дослідження об'єктів, які надійшли на експертизу та надання обгрунтованого, повного висновку. Результати автотехнічної експертизи після оцінки їхньої допустимості, достовірності та повноти можуть використовуватися як докази для вирішення обставин кримінального провадження про злочини проти безпеки руху та експлуатації транспорту.

Ключові слова: автотехнічна експертиза, висновок, оформлення, експерт, досудове розслідування.

In the article, on the basis of the analysis of scientific views of scientists and norms of the current legislation of Ukraine, the features of the conclusion of the forensic autotechnical examination are defined and characterized. It is substantiated that the results of the expert's assessment become grounds for other procedural actions, and thus may either shorten or extend the time of the pre-trial investigation and the settlement of the case in court. It is found that the research part of the expert's report describes the process of the research and its results, as well as justifies the conclusions on the questions raised. The research part should include: information on the state of the objects of research, the methods (methods) of the research applied, the conditions of their application; links to illustrations, applications, and related explanations; expert evaluation of the results of

(C) ЛУБЕНЦОВ А.В. - кандидат юридичних наук, завідувач лабораторії інженернотранспортних досліджень (Харківський науково-дослідний інститут судових експертиз імені заслуженого професора М.С. Бокаріуса) 
the study. The description of the process of applying instrumental research methods and conducting expert experiments may be limited to the presentation of the final results. In such cases, charts, diagrams, tables, materials of expert experiments should be kept in supervisory expert proceedings and, at the request of the body (s) who appointed the expert (s) (expert), may be provided to them for review. It is determined that the final part summarizes the findings of the study in the form of answers to the questions asked in the order defined in the introductory part. Each of these questions must be answered on the merits or stated for what reason it cannot be resolved. If the final conclusion cannot be summarized, references to the research findings set out in the research section are permitted. It is concluded that the process of carrying out auto-technical examination consists of a set of actions of organizational character of the head of the expert institution and the executor of the forensic examination, as well as actions of the cognitive, research nature of the forensic expert-motor technician, aimed at researching objects that have been submitted for examination and providing a substantiated conclusion. The results of an auto-technical examination, after assessing their admissibility, reliability and completeness, can be used as evidence to decide the circumstances of criminal proceedings for offenses against traffic safety and the operation of transport.

Key words: auto-technical examination, conclusion, design, expert, pre-trial investigation.

Вступ. Останнім часом в Україні збільшилась кількість дорожньо-транспортних пригод. У числі останніх особливу небезпеку та занепокоєння становлять пригоди із тяжкими чи смертельними наслідками, які за останній рік значно перевищили кількісні показники минулих звітних періодів. У зв'язку з цим першочерговим завданням правоохоронних органів $\epsilon$ повне та об'єктивне встановлення обставин подій, які відбуваються, збір достатніх доказів для з'ясування механізму злочину та винності учасників ДТП. Очевидно, що під час розслідування цієї категорії кримінальних проваджень не досить лише правових знань слідчого, тому здебільшого виникає необхідність у використанні спеціальних знань із різних галузей науки та техніки. Однією із форм використання спеціальних знань у кримінальному провадженні по фактам ДТП $\epsilon$ призначення автотехнічної експертизи, що обумовлено як специфікою об'єктів дослідження, так i особливостями методики призначення та проведення дослідження. Проведення експертизи $€$ складним процесом, який складається з великої кількості етапів, одним із найбільш відповідальних серед яких $€$ формування висновку.

Аналіз останніх досліджень і публікацій. Проблеми проведення судових автотехнічних експертиз були предметом дослідження значної кількості вчених, таких як П.О. Ананьєв, Є.Б. Бульбака, С.П. Варенікова, А.Я. Гордовер, Р.В.Грушин, С.В. Данець, У.Е. Ешанкулов, В.А. Іларіонов, В.І. Клименко, В.В. Косяков, О.Б. Кучерявенко, Е.П. Леневський, Ю.В. Пясецький, А.І. Овчаренко, С.О. Попов, М.С. Романов, О.В. Сараєв, Е.Б. Сімакова-Сфремян, А.М. Туренко, Ю.Г. Харченко, Ю.А. Шлепов та інші. Безумовно, вказані науковці зробили значний внесок у дослідження цієї проблематики. Однак здебільшого вони розглядали технічні та технологічні аспекти проведення автотехнічної експертизи. Поряд із цим залишились без уваги процесуальні та тактичні питання оформлення висновку експерта.

Постановка завдання. Метою статті є визначення та охарактеризування особливостей оформлення висновку судової автотехнічної експертизи.

Результати дослідження. Вимоги до форми та структури висновку викладені у відомчих нормативно-правових актах експертних установ, які передбачають, що висновок експерта складається з обов'язковим зазначенням його реквізитів (найменування документа, дати та номера складання висновку, категорії експертизи (додаткової, повторної, комісійної, комплексної), виду експертизи (за галуззю знань) та трьох частин: вступної (Вступ), дослідницької (Дослідження) та заключної (Висновки).

У вступній частині висновку експерта зазначаються: дата надходження документа про призначення експертизи (залучення експерта); найменування експертної установи та/або ім'я, прізвище, по батькові експерта; документ про призначення експертизи (залучення експерта), його найменування і дата складання, найменування органу та/або посада і прізвище особи, який (яка) призначив (-ла) експертизу (залучив (-ла) експерта); справа, за якою вона призначена (кримінальна, про адміністративне правопорушення, цивільна, господарська, адміністративна тощо, номер спра- 
ви); перелік об’єктів, що підлягають дослідженню, та зразків (у разі надходження); відомості про надані матеріали справи (зокрема, вид (назва) матеріалів (документів) і кількість аркушів); спосіб доставки та вид упаковки досліджуваних об'єктів із зазначенням за необхідності відомостей про те, чи впливав спосіб упаковки на їх збереженість; запис про відповідність матеріалів та об'єктів, що надійшли до експертної установи (експерта), матеріалам, зазначеним у документі про призначення експертизи (залучення експерта); перелік питань, які поставлено на вирішення експертизи; якщо питання сформульовано неясно або його редакція не відповідає рекомендаціям, але зміст завдання експертові зрозумілий, то після наведення питання в редакції документа про призначення експертизи він може дати відповідні роз'яснення і викласти питання в редакції, що відповідає зазначеним рекомендаціям; якщо поставлено декілька питань, експерт має право згрупувати їх і викласти в послідовності, яка забезпечує найдоцільніший порядок дослідження; якщо деякі питання, що містяться в документі про призначення експертизи, вирішувались під час проведення експертиз різних видів, відомості (експертна установа, номер і дата висновку) про ці експертизи; якщо питання, які поставлені на вирішення експертизи, доцільно вирішувати в іншому порядку, ніж той, що визначений у документі про призначення експертизи, зазначається, у якому порядку вирішуватимуться ці питання; питання, які вирішуються експертом у порядку експертної ініціативи (якщо таке розглядалось); дані про експерта (експертів): прізвище, ім'я та по батькові, посада, клас судового експерта, науковий ступінь та вчене звання, освіта, освітньо-кваліфікаційний рівень, експертна спеціальність, стаж експертної роботи, дата та номер видачі свідоцтва про присвоєння кваліфікації судового експерта, ким видано та строк дії; попередження експерта про кримінальну відповідальність за надання завідомо неправдивого висновку за ст. 384 КК України або за відмову від надання висновку за ст. 385 КК України; дата направлення клопотання експерта про надання додаткових матеріалів, дата надходження додаткових матеріалів або відомостей про наслідки розгляду клопотання; обставини справи, які мають значення для надання висновку, з обов'язковим зазначенням джерела їх отримання; під час проведення додаткових або повторних експертиз зазначаються відомості про первинну експертизу; зміст питань, які були поставлені перед експертом на додаткове або повторне вирішення, а також мотиви призначення додаткової або повторної експертизи, які зазначені в документі про призначення експертизи, якщо у ньому такі мотиви відсутні, про це робиться відповідний запис; відомості про процесуальні підстави та осіб, які були присутні під час проведення досліджень; нормативні акти, методики, рекомендована науково-технічна та довідкова література, інші інформаційні джерела, які використовувались експертом під час вирішення поставлених питань, із зазначенням реєстраційних кодів методик проведення судових експертиз із Реєстру методик проведення судових експертиз [1].

У дослідницькій частині висновку експерта описуються процес дослідження та його результати, а також дається обгрунтування висновків із поставлених питань. Дослідницька частина повинна включати таке: відомості про стан об'єктів дослідження, застосовані методи (методики) дослідження, умови їх застосовування; посилання на ілюстрації, додатки та необхідні роз'яснення до них; експертну оцінку результатів дослідження. Опис процесу застосовування інструментальних методів дослідження та проведення експертних експериментів можуть обмежуватись викладенням кінцевих результатів. У зазначених випадках графіки, діаграми, таблиці, матеріали експертних експериментів мають зберігатись у наглядових експертних провадженнях і на вимогу органу (особи), який (яка) призначив (-ла) експертизу (залучив (-ла) експерта), можуть надаватись їм для ознайомлення. За наявності в документі про призначення експертизи (залучення експерта) питань, які не належать до предмета експертизи або не входять до компетенції експерта, указуються причини, з яких ці питання не можуть бути вирішені. Узагальнення та оцінка результатів окремих досліджень, які є підставою для формулювання висновків, можуть викладатися в синтезуючому розділі дослідницької частини висновку експерта. У дослідницькій частині висновку експерта під час проведення повторної експертизи вказуються причини розбіжностей із висновками попередніх експертиз, якщо такі розбіжності мали місце [1].

У дослідницькій частині висновку слід чітко вказувати прийняті в розрахунках допущення, рекомендується обов'язково в розрахунках будувати схему ДТП в масштабі із зазначенням положень учасників у характерні моменти часу і з описом, зрозумілим для не спеціалістів. Виклад матеріалу проводиться в порядку логіки дослідження, який може відрізнятися від послідовності поставлених питань. Редакція деяких питань може бути змінена відповідно до знань експерта як технічного фахівця. Наприклад, питання про порушення ПДР не входить у компетенцію експерта, але його розглядають із відповіддю про відповідність (або невідповідність) дій із технічного боку конкретним вимогам ПДР, якими слід було керуватися в цій дорожній ситуації [2, с. 21]. 
У заключній частині викладаються висновки за результатами дослідження у вигляді відповідей на поставлені запитання в послідовності, що визначена у вступній частині. На кожне 3 поставлених запитань має бути дано відповідь по суті або вказано, з яких причин неможливо вирішити питання. Якщо заключний висновок не може бути сформульований у стислій формі, допускається посилання на результати досліджень, викладені в дослідницькій частині.

Висновок експерта (експертів) оформлюється на бланку експертної установи і підписується експертом (експертами), який (які) проводив (-ли) дослідження. Підписи в заключній частині засвідчуються відбитком печатки експертної установи на кожній сторінці тексту заключних висновків. Якщо до висновку експерта додаються фототаблиці, креслення, схеми, діаграми тощо, вони також підписуються експертом (експертами); підписи засвідчуються відбитком печатки експертної установи [1].

Кримінально-процесуальний кодекс (далі - КПК) України в ч. 8 ст. 101 встановлює, що якщо для проведення експертизи залучається кілька експертів, експерти мають право скласти один висновок або окремі висновки [3]. Якщо під час проведення комісійної судової експертизи (двома і більше судовими експертами) судові експерти дійшли згоди, вони підписують спільний висновок. Якщо судові експерти не дійшли згоди, складається кілька висновків відповідно до позицій судових експертів. Під час проведення комплексної судової експертизи (двома і більше судовими експертами) складається спільний висновок, який підписують усі судові експерти [4]. Для встановлення об'єктивної істини у кримінальних провадженнях, пов'язаних із ДТП, досить часто виникає необхідність у призначенні комплексних медичних та автотехнічних, трасологічних та автотехнічних або автотехнічних та експертиз матеріалів, речовин і виробів. Тому аналіз результатів таких досліджень повинен проводитися досить ретельно, оскільки, по суті, кожен із експертів своїм підписом підтверджує правильність і достовірність інших досліджень.

У системі джерел доказів особливе місце посідає висновок експерта, який є результатом втілення в судову практику загальнонаукового методу експертних оцінок на базі використання спеціальних знань у будь-якій галузі науки, техніки, мистецтва. На підставі проведених досліджень експертом встановлюються нові дані, які не є очевидними для суб'єктів доказування та належать до категорії особистих доказів, оскільки вони формуються і виходять від людини. Експерт під час проведення спеціалізованого дослідження, використовуючи всю різноманітність видів розумової діяльності і застосовуючи високоточні реєструючі й дослідницькі науково-технічні засоби, підходить до найвідповідальнішого етапу - до оцінки встановлених ознак і формулювання на підставі такої оцінки свого висновку. Останній у кожному випадку експертизи є підсумком пізнання об'єктивної дійсності [5, с. 28]. Звісно, такий підсумковий результат діяльності судового експерта має особливо велике значення в практиці досудового розслідування та судового розгляду справи, має високий авторитет для учасників кримінального процесу, оскільки оснований на спеціальних знаннях незацікавленої особи та вже відразу передбачає надійність встановлених відомостей.

Незважаючи на начебто явну перевагу над іншими доказами, висновок експерта у кримінальному провадженні підлягає оцінці особою, яка проводить досудове розслідування, або судом. Адже відповідно до ч. 10 ст. 101 КПК України висновок експерта не є обов'язковим для особи або органу, яка (який) здійснює провадження, але незгода з висновком експерта повинна бути вмотивована у відповідних постанові, ухвалі, вироку [3]. Наприклад, Р.С. Бєлкін, А.І. Вінберг та І.Л. Петрухін зазначили, що суд, прокурор, особа, яка проводить дізнання, можуть і повинні не тільки перевірити логіку експертного доказування, але й розібратися у висунутих експертом наукових положеннях, щоб переконатися в достовірності і повноті висновків експерта. Будь-яке судження експерта повинно пройти крізь призму внутрішнього переконання суду або слідчого до того як стати підставою висновків у справі [6, с. 226]. Враховуючи специфіку об'єктів дослідження автотехнічної експертизи, характер спеціальних знань і методів дослідження, оцінка такого висновку експерта для сторони розслідування стає досить складним процесом.

Вчені виділяють різні критерії оцінки висновку експерта. Однак, на нашу думку, найповніше та найсистемніше вони представлені О.Р. Россинською, яка виділяє сім стадій оцінки: 1) перевірку дотримання вимог закону під час призначення експертизи, яка полягає в з'ясуванні таких питань: чи компетентний експерт у вирішенні поставлених питань, чи не вийшов він за межі своєї компетенції; чи дотримано права учасників процесу під час призначення і проведення експертизи; чи немає порушень закону під час отримання зразків для порівняльного дослідження; чи дотримано процесуальну форму висновку експерта; 2) перевірку справжності, достовірності, належної якості, достатності речових доказів і зразків, що досліджувалися експертом; 3) оцінку 
наукової обгрунтованості експертної методики, а також правомірності та доцільності ії застосування в конкретному випадку; 4) перевірку і оцінку повноти експертного дослідження, яка дає підставу судити про повноту: дослідження всіх представлених на експертизу об'єктів; відповідей експерта на поставлені запитання; опису ходу і результатів дослідження, а також всіх передбачених відповідними методиками діагностичних, класифікаційних, ідентифікаційних ознак; 5) логічну обгрунтованість ходу і результатів експертного дослідження; 6) належність результатів експертизи до певної кримінальної справи; 7) відповідність висновків експерта наявним у справі доказам, тобто оцінку експертного висновку в сукупності з іншими доказами [7, с. 50-57].

Отже, оцінка висновку автотехнічної експертизи включає таке: а) оцінку виконання експертом процесуальних вимог і непорушення ним процесуальних обов'язків; б) дотримання формальних вимог до оформлення висновку експерта, наявності в ньому всіх складових частин; в) дослідження експертом усіх направлених об'єктів і відповідь на всі поставлені питання; г) логічний виклад матеріалу та обгрунтованість цих висновків; г) відповідність або суперечність іншим матеріалам кримінального провадження.

За результатами оцінки висновку експерта можуть прийматися такі рішення: 1) визнання висновку повним і обгрунтованим, а фактичних даних, що містяться в ньому, достовірними і такими, що мають значення у справі; 2) визнання висновку не досить ясним або неповним і за необхідності призначення додаткової експертизи або допит експерта для роз'яснення і доповнення даного ним висновку; 3) визнання висновку необгрунтованим або таким, що викликає сумніви в його правильності і за необхідності призначення повторної експертизи або проведення інших процесуальних дій, спрямованих на перевірку висновків експерта [8, с. 312]. Результати оцінки висновку експерта стають підставою для проведення інших процесуальних дій, а отже - можуть або скоротити, або розширити строки досудового розслідування та вирішення справи по суті в суді.

Висновки. Враховуючи викладене, можна зробити висновок, що процес проведення автотехнічної експертизи складається із сукупності дій організаційного характеру керівника експертної установи та виконавця судової експертизи, а також дій пізнавального, дослідницького характеру судового експерта-автотехніка, спрямованих на дослідження об'єктів, які надійшли на експертизу та надання обгрунтованого, повного висновку. Результати автотехнічної експертизи після оцінки їхньої допустимості, достовірності та повноти можуть використовуватися як докази для вирішення обставин кримінального провадження про злочини проти безпеки руху та експлуатації транспорту.

\section{Список використаних джерел:}

1.Про затвердження Положення про експертно-кваліфікаційні комісії та атестацію судових експертів : Наказ Міністерства юстиції України від 3 березня 2015 р. № 301/5 // База даних «Законодавство Украӥни» / Верховна Рада України. URL: http://zakon.rada.gov.ua/laws/show/z0249-15.

2.Балакин В. Д. Экспертиза дорожно-транспортных происшествий : учеб. пособие. 2-е изд., перераб. и доп. Омск : СибАДИ, 2010. 136 с.

3.Кримінальний процесуальний кодекс від 13 квітня 2012 р. № 4651-VI. Biдомості Bepховної Ради Украӥни. 2013. № 9-10, 11-12, 13. Ст. 88.

4.Про затвердження Інструкції з оформлення поліцейськими матеріалів про адміністративні правопорушення у сфері забезпечення безпеки дорожнього руху, зафіксовані не в автоматичному режимі : Наказ Міністерства внутрішніх справ України від 7 листопада 2015 р. № 1395 // База даних «Законодавство України» / Верховна Рада України. URL: http://zakon5.rada.gov.ua/ laws/show/z1408-15.

5.Гончаренко В.Г., Курдюков В.В., Легких К.В. Спеціальні знання: генезис, предмет, рівні, форми використання в доказуванні. Вісник Академії адвокатури України. 2007. Число 2 (9). С. 22-34.

6.Тлумачний словник основних термінів судової автотехнічної транспортно-трасологічної експертизи / укл.: В.Б.Кисельов, В.Д. Гардерман, П.В. Галаса. Київ : КНДІСЕ, 2000. 19 с.

7.Сафонов Г.И. Понятие судебной автотехнической экспертизы. Вестник Московского университета МВД России. № 12. 2015. С. 219-221.

8.Васильєв Ф.П. Доказывание по делу об административном правонарушении : дисс. ... докт. юрид. наук : 12.00.14. Москва, 2005. 403 с. 